\title{
IMPLEMENTASI PRINSIP MENGENAL NASABAH (KNOW YOUR CUSTOMER) SERTA PENGARUHNYA TERHADAP TINDAK PENCUCIAN UANG (MONEY LAUNDERING) DAN KINERJA KEUANGAN PADA LEMBAGA PERBANKAN
}

\author{
Julyana Wijaya \\ Fakultas Ilmu Sosial dan Humaniora, Universitas Bunda Mulia \\ email: jwijaya@bundamulia.ac.id
}

\begin{abstract}
The purpose of this paper is to examine the effect of the implementation of Know Your Customer to the banks financial performance. Quantitaive description analysis was used to evaluate the answers of 26 respondents from a questionnaire. Descriptive statistic shows that 60\%-70\% respondents agreed that there is an effect from the implementation of KYC against money laundering action and financial performance of financial institution. However regression analysis shows that there is no significant effect between implementation of KYC and financial performance of financial institution.
\end{abstract}

Keywords: Money Laundering, Know Your Customer, Fiancial Performance

Abstrak

Penelitian ini bertujuan untuk menganalisis mengenai bagaimana implementasi Prinsip Mengenal Nasabah (KYC) dalam upaya mencegah pencucian uang yang dilakukan oleh lembaga perbankan di Indonesia serta pengaruhnya terhadap pencucian uang (money laundering) dan kinerja keuangan dalam lembaga perbankan. Pendekatan dengan metode penelitian deskriptif kuantitatif, dengan menyebarkan kuesioner ke 26 responden. Dilihat dari hasil statistik deskriptif sekitar $60 \%-70 \%$ responden yang menyatakan ada pengaruh dari implementasi mengenal nasabah terhadap terindikasinya pencucian uang dan kinerja keuangan (DPK) perbankan.Akan tetapi melalui hasil uji statistik diketahui bahwa tidak ada pengaruh yang signifikan baik dari implementasi mengenal nasabah terhadap pencucian uang maupun dari implementasi mengenal naabah terhadap kinerja keuangan (DPK) perbankan. Penelitian ini juga dapat dikembangkan untuk melihat seberapa jauh terpengaruhnya kinerja keuangan (DPK) perbankan secara kuantitatif.

Kata Kunci: Pencucian Uang, Prinsip Mengenal Nasabah, Kinerja Keuangan

PENDAHULUAN

Hasil penelitian yang

dilakukan oleh Transparency

Internasional (TI), Indonesia

termasuk dalam daftar negara yang

memiliki korupsi tingkat tinggi.
Dengan nilai Corruption Perception Index (CPI) atau Indeks Persepsi Korupsi sebesar 34 poin, menduduki peringkat ke 109 dari 175 daftar negara terbersih dan terkorup di dunia (Tempo 2014). 
Skor Indonesia ini masih di bawah persepsi korupsi rata-rata negaranegara dunia yaitu 43 poin, dimana skala 0 menunjukan persepsi sangat korup dan 100 dinilai sangat bersih.

Di era pemerintahan Presiden Susilo Bambang Yudhoyono (SBY), upaya pemberantasan korupsi dilakukan cukup sistematis, antara lain mendukung terbentuknya lembaga khusus Komisi Pemberantasan Korupsi (KPK) yang didasari olehUndang-Undang Nomor 30 Tahun 2002.

Pemerintah juga mendirikan lembaga independen lain yang berdasarkan Undang-Undang Nomor 15 Tahun 2002 yaitu Pusat Pelaporan dan Analisis Transaksi Keuangan (PPATK) dimana lembaga ini bertanggung jawab dalam menangani dan mengatasi adanya kegiatan pencucian uang (money laundering).

Kegiatan pencucian uang merupakan salah satu upaya koruptor dalam mengaburkan asalusul uang tersebut sehingga nampak berasal dari sumber yang sah.
Tahapan dalam dalam pencucian uang meliputi kegiatan menempatkan uang hasil kejahatannya ke dalam sistem keuangan (placement), melapisi uang tersebut dengan berbagai transaksi keuangan (layering), dan menyatukannya kembali kepada pelaku utama kejahatan asal (integration) (McLaughin and Pavelka 2004). Sistem keuangan yang sudah lintas Negara dan terintegrasi dalam sistem keuangan global, tidak dapat menutup kemungkinan akan masuknya danadana ilegal yang berasal dari pencucian uang.

Perbankan termasuk ke dalam salah satu sistem keuangan yang merupakan sarana utama kegiatan pencucian uang. Pemanfaatannya dengan fasilitas transfer dan menyembunyikan asal-usul dana. Menyiasati hal tersebut lembaga perbankan saat ini dituntut untuk melakukan mekanisme dalam pencegahan praktek kegiatan pencucian uang yang dapat dilakukan oleh nasabah ataupun calon nasabahnya. 
Adanya dukungan Bank Lembaga perbankan harus Indonesia tercermin dalam mengendalikan risiko dan penerbitan Program Anti Pencucian mencegah dipergunakannya bank Uang dan Pencegahan Pendanaan Terorisme (APU dan PPT). Dalam rangka mewujudkan APU dan PPT yang lebih optimal, Bank Indonesia secara aktif dan berkoordinasi dengan instansi terkait antara lain Pusat Pelaporan dan Analisis Transaksi Keuangan (PPATK), Komisi Pemberantasan Korupsi (KPK), Badan Pengawas Pasar Modal dan Lembaga Keuangan (Bapepam LK) yang kini telah berganti menjadi Otoritas Jasa Keuangan (OJK). Penerapan program APU dan PPT oleh lembaga perbankan tidak saja penting untuk pemberantasan pencucian uang, melainkan juga untuk mendukung penerapan prudential banking (prinsip kehatihatian) yang dapat melindungi bank dari berbagai risiko yang mungkin timbul antara lain risiko hukum, risiko reputasi, risiko operasional dan risiko konsentrasi (Bank Indonesia 2014). sebagai sarana untuk melakukan pencucian uang. Maka dari itu Bank Indonesia mengeluarkan peraturan untuk lembaga-lembaga perbankan yaitu yang terbaru adalah Peraturan Bank Indonesia Nomor : 14/27/PBI/2012 tanggal 28 Desember 2012 tentang Penerapan Program Anti Pencucian Uang dan Pencegahan Pendanaan Terorisme Bagi Bank Umum dan Surat Edaran Bank Indonesia No. 15/21/DPNP Tanggal 14 Juni 2013 Tentang Penerapan Program Anti Pencucian Uang Dan Pencegahan Pendanaan Terorisme Bagi Bank Umum, yang menitikberatkan kepada Prinsip Mengenal Nasabah (KYC) atau sering dikenal dengan Know Your Customer (KYC) dimana fungsi pokoknya adalah selain untuk mengenal dan mengetahui identitas nasabah, juga memantau kegiatan transaksi nasabah termasuk melaporkan setiap transaksi yang mencurigakan, guna mencegah kegiatan pencucian uang di bank. 
Hal ini merupakan peraturan yang berkaitan langsung dan didasarkan oleh Undang-Undang Nomor 8 Tahun 2010 tentang Pencegahan dan Pemberantasan Tindak Pidana Pencucian Uang. Sehingga dapat dirumuskan bahwa yang menjadi fokus penelitian ini adalah untuk melihat bagaimana implementasi Prinsip Mengenal Nasabah (KYC) yang ditetapkan oleh Bank Indonesia serta pengaruhnya terhadap pencucian uang dan kinerja keuangan dalam lembaga perbankan.

Penelitian ini bertujuan untuk menganalisis mengenai bagaimana implementasi Prinsip Mengenal Nasabah (KYC) dalam upaya mencegah pencucian uang yang dilakukan oleh lembaga perbankan di Indonesiaserta pengaruhnya terhadap pencucian uang (money laundering) dan kinerja keuangan dalam lembaga perbankan.

Urgensi yang penulis angkat dalam penelitian ini pertama, Apakah lembaga perbankan saat ini sudah benar-benar mengimplementasikan Prinsip
Mengenal Nasabah (KYC) sesuai dengan standar program yang ditetapkan oleh Bank Indonesia? Kedua apakah ada pengaruh dari penerapan Prinsip Mengenal Nasabah (KYC) yang dilakukan terhadap terdeteksinya tindak pencucian uang dalam lembaga perbankan?, ketiga, apakah ada pengaruh dari penerapan Prinsip Mengenal Nasabah (KYC) terhadap kinerja keuangan lembaga perbankan?

\section{RERANGKA KONSEPTUAL DAN HIPOTESIS}

Rerangka konseptual pemikiran dalam penelitian ini, terangkum dalam gambar 1. Menurut Surat Edaran Bank Indonesia Nomor: 11/3/DPNP tanggal 30 November 2009 mengenai Pedoman Standar Penerapan Program Anti Pencucian Uang dan Pencegahan Pendanaan Terorisme bagi bank Umum, terdapat beberapa prosedur dalam pelaksanaan Prinsip Mengenal Nasabah (KYC), yaitu prosedur penerimaan, identifikasi, dan verifikasi (Customer Due Diligence), prosedur 
pengelompokan

nasabah

berdasarkan risiko (Risk Based

Approach), prosedur transaksi

rekening nasabah, dan prosedur

sistem pengendalian intern.

Berdasarkan Pedoman Identifikasi

Transaksi Keuangan Mencurigakan

bagi Penyedia Jasa Keuangan yang

diterbitkan oleh PPATK Nomor :

2/4/KEP/PPATK/2003, unsur-unsur

dan indikator Transaksi Keuangan
Mencurigakan meliputi transaksi (tunai dan transfer dana) dan perilaku nasabah (informasi yang tidak benar, menolak memberikan informasi, mempengaruhi petugas untuk tidak melaporkan). Dalam menilai pengaruhnya terhadap kinerja keuangan perbankan, penulis menggunakan indikator tingkat pembukaan rekening baru, dan tingkat dana pihak ketiga.

\section{Gambar.1}

\section{Rerangka Konseptual}

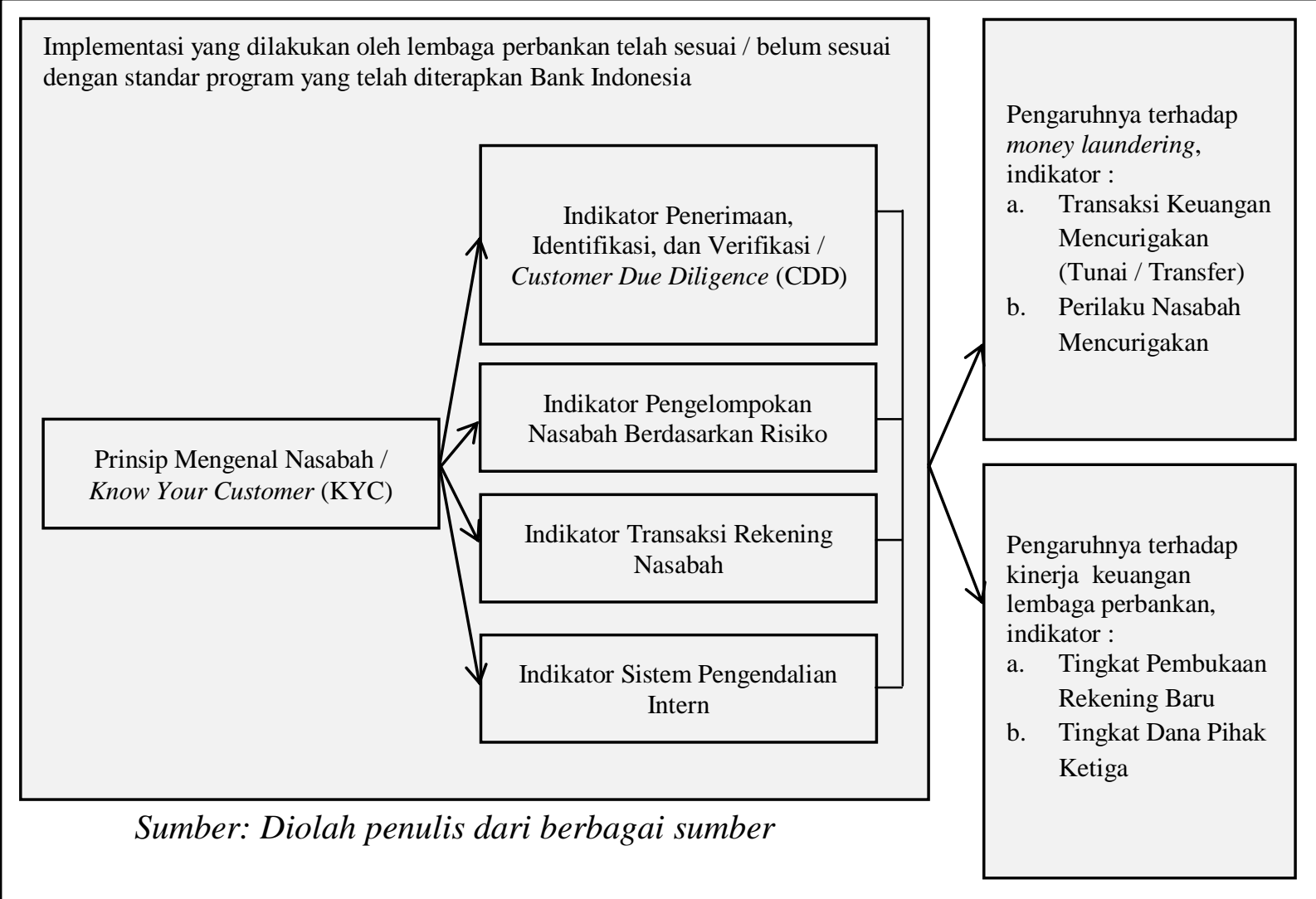




\section{Dana Pihak Ketiga (DPK)} perbankan, dimana apakah dengan adanya KYC ini mempengaruhi tingkat DPK lembaga perbankan. Penelitian ini merupakan pengembangan dari beberapa penelitian sebelumnya, yang terangkum dalam tabel terlampir.

Dari rerangka konseptual dan

penelitian terdahulu yang dilakukan, maka dikembangkan hipotesis

sebagai berikut:

Hipotesis nol $\left(\mathrm{Ho}_{1}\right)$ : tidak ada pengaruh antara pelaksanaan KYC terhadap money laundering di lembaga perbankan

Hipotesis alternatif $\left(\mathrm{Ha}_{1}\right)$ : ada pengaruh antara pelaksanaan KYC terhadap money laundering di lembaga perbankan

Hipotesis nol $\left(\mathrm{Ho}_{2}\right)$ : tidak ada pengaruh antara pelaksanaan KYC terhadap kinerja keuangan perbankan

Hipotesis alternatif $\left(\mathrm{Ha}_{2}\right)$ : ada pengaruh antara pelaksanaan KYC terhadap kinerja keuangan perbankan

\section{METODE PENELITIAN}

Pendekatan dengan metode penelitian deskriptif kuantitatif, di mana penelitian deskriptif dapat dilakukan secara kuantitatif agar dapat dilakukan analisis statistik. Pengumpulan data dalam penelitian menggunakan metode (Basuki 2010) :

a. Observasi Non Partisipan Mengamati dan mencatat kegiatan penerapan KYC di perbankan apakah sudah sesuai prosedur yang diterapkan Bank Indonesia.

b. Kuesioner

Pertanyaan terstruktur yang diisi sendiri oleh responden atau diisi oleh pewawancara yang membacakan pertanyaan dan kemudian mencatat jawaban yang berikan. Dalam kuesioner diberikan pertanyaan yang menyangkut fakta dan pendapat responden, dan digunakan kuesioner tertutup dimana responden diminta menjawab 
pertanyaan dengan memilih

dari sejumlah alternatif.

c. Wawancara Terstruktur

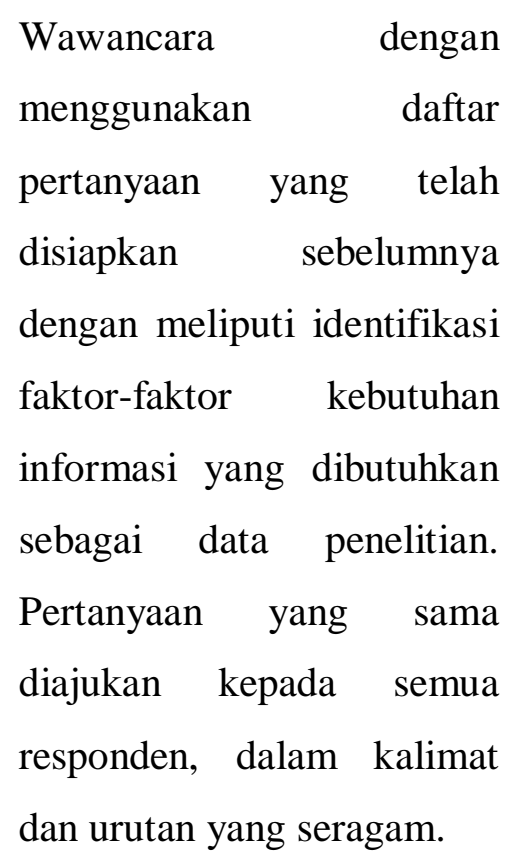

Berdasarkan perolehan data, pertama penelitian ini bersifat teks analysis /studies. Artinya penelitian bertujuan untuk memberikan gambaran sistematis, faktual dan akurat terkait fakta dan sifat dari objek penelitian. Penulis menggambarkan objek yang diteliti melalui studi kepustakaan, yaitu pengumpulan data dengan jalan mempelajari jurnal ilmiah, makalah seminar, hasil penelitian, dan peraturan perUndang-Undangan yang terkait dengan permasalahan yang diteliti.
Selain menggunakan penelitian teks analysis/studies, penelitian ini juga menggunakan metode field reseacrh yaitu penelitian lapangan yang dilakukan secara langsung kepada pimpinan bank maupun karyawan yang disposisikan sehingga dapat sebagai narasumber (responden). Objek penelitian yang dimaksud dalam penelitian ini merupakan lembaga perbankanyang terdaftar di BEI (Bursa Efek Indonesia). Dari penelusuran informasi BEI (IDX Statistic Book 2014) yang dilakukan, diperoleh ada sebanyak 36 Bank yang akan dijadikan sebagai responden penelitian.

Dalam melakukan kunjungan ke 36 responden, dilakukan dengan menyebarkan kuisioner dan wawancara sesuai dengan pertanyaan yang telah disiapkan oleh penulis untuk melihat pelaksanaan Prinsip Mengenal Nasabah (KYC) dalam upaya mencegah pencucian uang yang dilakukan oleh perbankan. Secara garis besar pertanyaan yang 
diajukan kepada responden terdiri dari 3 kelompok pertanyaan :

1. Kelompok pertama berkaitan dengan profil responden itu sendiri yang bertujuan untuk melihat demografi responden yang terdiri dari jenis kelamin, usia, jenjang pendidikan formal terakhir, jabatan yang sedang dijalani, masa kerja di posisi sekarang, serta rata-rata jumlah pelatihan/lokakarya yang diikuti oleh responden dalam setahun.

2. Kelompok kedua berkaitan dengan tujuan penelitian yaitu untuk melihat bagaimana pelaksanaan Prinsip Mengenal Nasabah (KYC) dalam upaya mencegah pencucian uang yang dilakukan oleh perbankan. Terdiri dari 4 kelompok pertanyaaan secara garis besar yang merupakan indicator Pedoman Standar Penerapan Prinsip Mengenal Nasabah
(KYC) yang telah ditetapkan oleh Bank Indonesia :

a. Indikator Penerimaan Calon Nasabah atau Customer Due Diligence (CDD)

Meliputi : prosedur penerimaan nasabah, prosedur identifikasi dan verifikasi, prosedur persetujuan penerimaan calon nasabah, prosedur dokumentasi profil nasabah.

b. Indikator

Pengelompokan

Nasabah (Risk Based Approach)

Meliputi pengelompokan nasabah menggunakan pendekatan berdasarkan risiko, dan penetapan profil risiko menggunakan pendekatan berdasarkan risiko.

c. Indikator Transaksi Nasabah 


$$
\begin{array}{lr}
\text { Meliputi : } & \text { prosedur } \\
\text { pemantauan } & \text { rekening } \\
\text { dan identifikasi transaksi, } & \text { identifikasi } \\
\text { prosedur } \quad \text { keuangan } \\
\text { transaksi } \\
\text { mencurigakan, }
\end{array}
$$

d. Indikator Pengendalian

Intern

Meliputi : pemisahan

tugas dan tanggung

jawab antara pelaksana

kebijakan pemutus

transaksi dan pemisahan

tugas dan tanggung

jawab antara pelaksana

kebijakan dan pengawas

penerapan kebijakan.

3. Kelompok ketiga berkaitan dengan tujuan penelitian yang melihat adakah pengaruh dari pelaksanaan KYC terhadap money laundering dan kinerja keuangan dalam lembaga perbankan.
a. Indikator
Pengaruh
Pelaksanaan

terhadap terdeteksinya money laundering

Meliputi : setelah diterapkannya $\mathrm{KYC}$ berdampak pada terindikasinya tingkat money laundering yang terjadi dalam lembaga perbankan, yaitu Transaksi Keuangan Mencurigakan meliputi transaksi (tunai dan transfer dana) dan perilaku nasabah (informasi yang tidak benar, menolak memberikan informasi, mempengaruhi petugas untuk tidak melaporkan). b. Indikator Pengaruh Pelaksanaan KYC terhadap kinerja perbankan

Meliputi: indikator yaitu tingkat Dana Pihak Ketiga (DPK) perbankan, dimana apakah dengan adanya KYC ini mempengaruhi perkembangan tingkat 
DPK lembaga

perbankan.

\section{Teknik Analisis Data}

Penelitian ini menggunakan 2 metode analisis, yaitu:

a. Penelitian deskriptif dengan teks analysis/studiessebagai metode analisis data yaitu data yang telah diperoleh akan disusun secara sistematis dan selanjutnya dianalisis secara kualitatif untuk mencapai kejelasan dari tujuan penelitian.

b. Penelitian field research, dimana data yang digunakan adalah studi lapangan yaitu berusaha untuk memperoleh data primer langsung dari narasumber, baik pimpinan maupun karyawan yang didisposisikan.

Metode penelitian yang dilakukan adalah penelitian deskriptif kuantitatif yaitu penelitian yang dirancang untuk memperoleh informasi tentang status suatu gejala saat penelitian dilakukan. Penelitian deskriptif merupakan penelitian yang berusaha untuk mendeskripsikan sesuatu, misalkan suatu keadaaan, hubungan sebab akibat, akibat atau efek, serta keadaaan atau proses yang sedang berlangsung. Adapun variabel dalam penelitian ini adalah sebagai berikut, variabel bebas atau independen (X) yaitu Prinsip Mengenal Nasabah (KYC) dengan indikator:
a. Penerimaan Calon Nasabah atau Customer Due Diligence (CDD)
b. Pengelompokan Nasabah (Risk Based Approach)
c. Transaksi Rekening Nasabah

d. Sistem Pengendalian Intern Variabel terikat atau dependen (Y)yang meliputi :
a. Money Laundering
b. Kinerja Keuangan

Dengan menggunakan variabelvariabel di atas, dibentuk dua buah persamaan, yaitu persamaan pertama :

$$
\gamma_{1}=\alpha+\beta \chi_{1}
$$


untuk melihat apakah ada pengaruh dari faktor $\mathrm{X}_{1}$ yaitu (KYC) terhadap $\mathrm{Y}_{1}$ (Money Laudering) dalam perusahaan perbankan. Dan persamaan kedua yaitu:

$$
\gamma_{2}=\alpha+\beta \chi_{1}
$$

untuk melihat apakah ada pengaruh dari faktor $\mathrm{X}_{1}$ yaitu (KYC) terhadap $\mathrm{Y}_{2}$ (Kinerja Keuangan) dalam perusahaan perbankan.

Dalam penelitian ilmiah sangat dibutuhkan kecermatan pengukuran dengan dua syarat utama, yaitu (Hasan 2006) :

1. Validitas artinya alat ukur yang digunakan dalam pengukuran, dapat digunakan untuk mengukur apa yang hendak diukur. Uji validitas dimaksudkan untuk menguji ketepatan item-item dalam kuesioner, apakah item-item yang ada mampu menggambarkan dan menjelaskan variabel yang diteliti. Jadi validitas adalah seberapa jauh alat dapat mengukur hal atau subjek yang ingin diukur.

2. Reliabilitas artinya memiliki sifat dapat dipercaya, yaitu apabila alat ukur digunakan berkali-kali oleh peneliti yang sama atau oleh peneliti lain tetap memberikan hasil yang sama. Jadi reliabilitas adalah seberapa jauh konsistensi alat ukur untuk dapat memberikan hasil yang sama dalam mengukur hal dan subjek yang sama.
Dalam pemberian skor digunakan skala Likert yang merupakan salah satu cara untuk menentukan skor. Kriteria penilaian ini digolongkan dalam empat tingkatan dengan penilaian sebagai berikut (Jogiyanto 2013):
1. Jawaban A, diberi skor 5 (Kategori Sangat)
2. Jawaban B, diberi skor 4 (Kategori Agak)
3. Jawaban $\mathrm{C}$, diberi skor 3 (Kategori Netral)

4. Jawaban D, diberi skor 2 (Kategori Kurang) 
5. Jawaban E, diberi skor 1 (Kategori Tidak)

Metode analisis yang digunakan dalam penelitian ini adalah Analisis Deskriptif Persentase. Metode ini digunakan untuk mengkaji variabel yang ada pada penelitian yaitu money laundering $\left(\mathrm{Y}_{1}\right)$ dan Dana Pihak Ketiga $\left(\mathrm{Y}_{2}\right)$ serta Know Your Customer (X). Deskriptif persentase ini diolah dengan cara frekuensi dibagi dengan jumlah responden dikali 100 persen, seperti dikemukan Sudjana (2001) adalah sebagai berikut:

$$
P=\frac{f}{N} \times 100 \%
$$

Keterangan :

$$
\begin{array}{ll}
\mathrm{P} & =\text { persentase kategori } \\
\mathrm{f} & =\text { frekuensi kategori } \\
\mathrm{N} & =\text { jumlah responden }
\end{array}
$$

Pengujian hipotesis adalah suatu prosedur yang akan menghasilkan suatu keputusan, yaitu keputusan dalam menerima atau menolak hipotesis ini (Hasan 2006). Uji hipotesis yang digunakan dalam penelitian ini adalah $\mathrm{Uji} \mathrm{t}$ atau distribusi t, melalui langkahlangkah berikut:

\section{ANALISIS DAN PEMBAHASAN}

Hasil pengambilan data dengan melakukan kunjungan ke 36 Bank yang dijadikan sebagai responden dalam penelitian berdasarkan kriteria yang telah ditetapkan diawal, maka dari hasil lapangan yang diperoleh, menunjukan bahwa jumlah kuisioner yang dapat diolah (kembali) ada sebanyak 26 kuisioner atau dengan tingkat pengembalian 72,22\%. Agar lebih jelas, dalam hal ini penulis menyajikan jumlah kuisioner yang dibagikan dan yang kembali dalam tabel dibawah ini.

Tabel 1

Sampel dan Tingkat Pengembalian / Respon Responden

\begin{tabular}{|l|c|c|}
\hline \multirow{2}{*}{ Keterangan } & \multicolumn{2}{|c|}{ Responden } \\
\cline { 2 - 3 } & Jumlah & Persentase \\
\hline $\begin{array}{l}\text { Kuisioner } \\
\text { yang } \\
\text { disebarkan }\end{array}$ & 36 & $100 \%$ \\
\hline $\begin{array}{l}\text { Kuisioner } \\
\text { yang kembali }\end{array}$ & 26 & $72,22 \%$ \\
\hline $\begin{array}{l}\text { Kuisioner } \\
\text { yang tidak } \\
\text { direspon }\end{array}$ & 10 & $27,78 \%$ \\
\hline $\begin{array}{l}\text { Kuisiner yang } \\
\text { dapat diolah }\end{array}$ & 26 & $72,22 \%$ \\
\hline
\end{tabular}

Sumber : diolah penulis 
Pertanyaan kuesioner kelompok pertama berkaitan dengan profil responden. Target adalah Pimpinan Cabang Bank (atau karyawan yang didisposisikan), karena diasumsikan seorang Pimpinan Cabang dapat mengetahui secara pasti kondisi cabang yang dipegangnya serta bagaimana implementasi KYC pada cabangnya berada serta berkaitan langsung dengan nasabah sehingga dapat merasakan dampak secara langsung terhadap money laundering maupun Dana Pihak Ketiga (diasumsikan suatu cabang dapat mewakili bank tersebut, karena sistem dan prosedur serta budaya suatu bank pasti akan ditularkan juga pada setiap cabangnya).
Gambar 2

Profil Responden Berdasarkan Jabatan

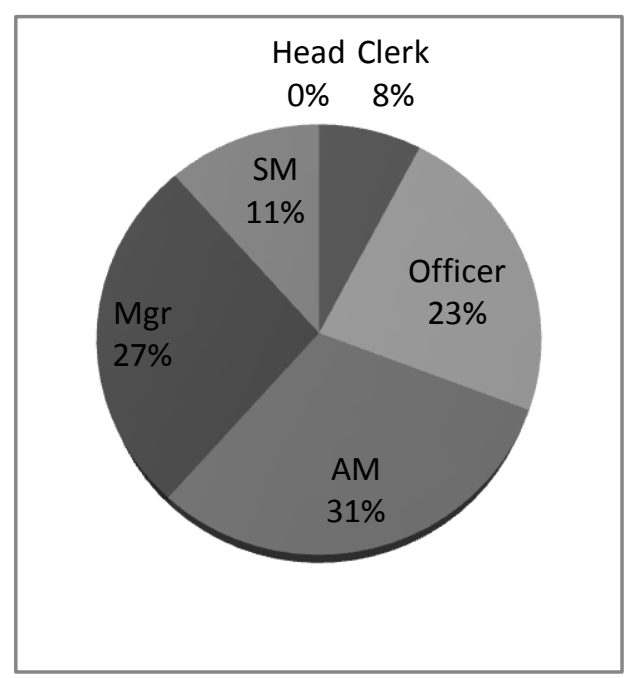

Sumber : diolah penulis

Pertanyaan kuesioner

kelompok kedua berkaitan dengan tujuan penelitian yaitu untuk melihat bagaimana pelaksanaan prinsip mengenal nasabah (KYC) dengan indikator implementasi pedoman standar penerapan Prinsip Mengenal Nasabah (KYC). Prosedur penerimaan calon nasabah, yang dimulai dari bank melakukan permintaan informasi mengenai calon nasabah dan informasi lain yang memungkinkan Bank untuk dapat mengetahui profil calon Nasabah, Bank melakukan permintaan bukti-bukti identitas dan dokumen pendukung informasi dari 
calon nasabah, dan Bank melakukan penelitian atas kebenaran dokumen pendukung identitas calon nasabah, ketiga hal ini merupakan suatu komponen utama yang harus diperhatikan oleh setiap perbankan sebelum menerima calon nasabah. Salah satu yang harus diperhatikan adalah Bank harus dapat mendapatkan informasi calon nasabah dan meminta bukti identitas serta meyakinkan kebenaran dokumen tersebut. Hal ini bertujuan agar jika dikemudian hari terdapat transaksi keuangan mencurigakan yang dilakukan nasabah tertentu hal ini dapat ditindak lanjuti dengan cepat karena Bank benar-benar dapat meyakinkan bahwa nasabah tersebut merupakan nasabah yang memiliki latar belakang yang jelas. Dalam hal ini, dari penelusuran yang dilakukan, semua responden menyatakan bahwa ditempat mereka bekerja terdapat prosedur penerimaan calon nasabah dan yakin bahwa prosedur tersebut telah diberlakukan dengan efektif. a. Sebanyak $99 \%$ responden setuju bahwa Bank tempat mereka bekerja terdapat adanya prosedur penerimaan calon nasabah

b. Sebanyak $92 \%$ responden setuju bahwa Bank tempat mereka bekerja melakukan pengelompokan nasabah berdasarkan risiko

c. Sebanyak $88 \%$ responden setuju bahwa Bank tempat mereka bekerja melakukan pemantauan rekening dan transaksi nasabah

d. Sebanyak 93\% responden setuju bahwa Bank tempat mereka bekerja memiliki sistem pengendalian intern

Pertanyaan kuesioner kelompok ketiga berkaitan dengan tujuan penelitian yang melihat adakah pengaruh dari pelaksanaan KYC terhadap money laundering dan kinerja keuangan dalam lembaga perbankan. Dalam hal ini, pertanyaan yang ingin diajukan adalah untuk melihat apakah pernah terdapat adanya Transaksi 
Keuangan Mencurigakan yang pernah terjadi pada Bank. Setelah mengetahui apakah ada tidaknya transaksi mencurigakan, kemudian ditanyakan kembali apakah terdapat pengaruh implementasi KYC untuk mengantisipasi tindak transaksi keuangan mencurigakan, dan bagaiama kaitannya dengan kinerja keuangan perbankan.

a. Indikator pengaruh pelaksanaan KYC terhadap terdeteksinya Money

Laundering :

1. Sebanyak $62 \%$ responden setuju bahwa setelah diterapkannya $\quad \mathrm{KYC}$ berdampak pada terindikasinya nasabah yang menolak memberikan informasi, memberikan informasi tidak benar dan perilaku nasabah yang mempengaruhi petugas

2. Sebanyak $72 \%$ responden setuju bahwa setelah diterapkannya $\quad \mathrm{KYC}$ berdampak pada terindikasinya transaksi keuangan mencurigakan baik secara tunai maupun transfer

b. Indikator pengaruh pelaksanaan $\mathrm{KYC}$ terhadap kinerja keuangan perbankan :

1. Sebanyak $74 \%$ responden setuju bahwa setelah diterapkannya $\quad \mathrm{KYC}$ berdampak pada perkembangan pembukaan rekening baru

2. Sebanyak $72 \%$ responden setuju bahwa setelah diterapkannya $\quad \mathrm{KYC}$ berdampak pada pertumbuhan tingkat Dana Pihak Ketiga (DPK)

\section{Uji Validitas Terhadap}

\section{Instrumen (Kuesioner)}

\section{Uji Validitas Variabel Y1 :}

Nilai r-tabel dapat diperoleh melalui $\mathrm{df}($ degree of freedom $)=\mathrm{n}$ - k, dimana $\mathrm{k}$ merupakan jumlah butir pertanyaan dalam suatu variabel, dan $\mathrm{n}$ merupakan jumlah responden. Maka df $=26-5=21$. Tabel $\mathrm{r}$ product - moment (two tailed test) menunjukkan bahwa 
pada df 21 dengan alpha 5\%, diperoleh $\underline{\text { rtable sebesar }} 0,413$

Tabel 2 Hasil Uji Validitas Variabel Y1

Item-Total Statistics

\begin{tabular}{|r|r|r|r|r|}
\hline & $\begin{array}{c}\text { Scale Mean if } \\
\text { Item Deleted }\end{array}$ & $\begin{array}{c}\text { Scale } \\
\text { Variance if } \\
\text { Item Deleted }\end{array}$ & $\begin{array}{c}\text { Corrected } \\
\text { Item-Total } \\
\text { Correlation }\end{array}$ & $\begin{array}{c}\text { Cronbach's } \\
\text { Alpha if Item } \\
\text { Deleted }\end{array}$ \\
\hline PY1.1 & 12.88 & 16.986 & .600 & .876 \\
PY1.2 & 13.00 & 13.760 & .822 & .822 \\
PY1.3 & 14.15 & 19.815 & .429 & .905 \\
PY1.4 & 12.77 & 14.265 & .871 & .808 \\
PY1.5 & 12.88 & 14.906 & .837 & .819 \\
\hline
\end{tabular}

Sumber : diolah penulis

Uji Validitas Variabel Y2 :

Nilai r-tabel dapat diperoleh melalui $\mathrm{df}($ degree of freedom $)=\mathrm{n}$ - $\mathrm{k}$, dimana $\mathrm{k}$ merupakan jumlah butir pertanyaan dalam suatu variabel, dan $\mathrm{n}$ merupakan jumlah responden. Maka df $=26-5=21$. Tabel $\mathrm{r}$ product - moment (two tailed test) menunjukkan bahwa pada df 21 dengan alpha 5\%, diperoleh $\underline{\text { rtable sebesar } \quad 0,413}$
Tabel 3

Hasil Uji Validitas Variabel Y2

\begin{tabular}{|l|r|r|r|r|}
\multicolumn{5}{|c|}{ Item-Total Statistics } \\
\hline & $\begin{array}{c}\text { Scale Mean if } \\
\text { Item Deleted }\end{array}$ & $\begin{array}{c}\text { Scale } \\
\text { Variance if } \\
\text { Item Deleted }\end{array}$ & $\begin{array}{c}\text { Corrected } \\
\text { Item-Total } \\
\text { Correlation }\end{array}$ & $\begin{array}{c}\text { Cronbach's } \\
\text { Alpha if Item } \\
\text { Deleted }\end{array}$ \\
\hline PY2.1 & 14.58 & 27.054 & .628 & .972 \\
PY2.2 & 14.85 & 21.255 & .958 & .918 \\
PY2.3 & 14.77 & 20.665 & .903 & .930 \\
PY2.4 & 14.92 & 21.834 & .920 & .925 \\
PY2.5 & 14.88 & 22.826 & .907 & .929 \\
\hline
\end{tabular}

\section{Sumber : diolah penulis}

Berdasarkan hasil perhitungan ini, dapat disimpulkan lima indikator pertanyaan variabel Y2 memiliki $\mathrm{r}$ hitung yang lebih besar dari nilai $r$ tabel telah valid.

\section{Uji Validitas Variabel X :}

Nilai r-tabel dapat diperoleh melalui df (degree of freedom $)=\mathrm{n}$ - k, dimana $\mathrm{k}$ merupakan jumlah butir pertanyaan dalam suatu variabel, dan $\mathrm{n}$ merupakan jumlah responden. Maka df $=26-7=19$. Tabel $\mathrm{r}$ product - moment (two tailed test) menunjukkan bahwa pada df 19 dengan alpha 5\%, diperoleh $\mathrm{r}$ tabel sebesar 0,433 
Tabel 4

Hasil Uji Validitas Variabel $\mathbf{X}$

\begin{tabular}{|l|r|r|r|r|}
\multicolumn{5}{|c|}{ Item-Total Statistics } \\
\hline & $\begin{array}{c}\text { Scale Mean if } \\
\text { Item Deleted }\end{array}$ & $\begin{array}{c}\text { Scale } \\
\text { Variance if } \\
\text { Item Deleted }\end{array}$ & $\begin{array}{c}\text { Corrected } \\
\text { Item-Total } \\
\text { Correlation }\end{array}$ & $\begin{array}{c}\text { Cronbach's } \\
\text { Alpha if Item } \\
\text { Deleted }\end{array}$ \\
\hline PX.1 & 27.92 & 3.834 & .000 & .625 \\
PX.2 & 27.92 & 3.834 & .000 & .625 \\
PX.3 & 28.08 & 3.434 & .194 & .605 \\
PX.4 & 28.31 & 2.862 & .334 & .566 \\
PX.5 & 28.54 & 2.018 & .584 & .445 \\
PX.6 & 28.50 & 2.660 & .297 & .594 \\
PX.7 & 28.27 & 2.365 & .668 & .428 \\
\hline
\end{tabular}

Sumber : diolah penulis

Berdasarkan hasil perhitungan ini, dapat disimpulkan dua indikator pertanyaan variabel $\mathrm{X}$ dalam penelitian ini memiliki $r$ hitung yang lebih besar dari nilai $\mathrm{r}$ tabel, telah valid, sedangkan untuk butir pertanyaan $1,2,3,4$ dan 6 dinyatakan tidak valid karena memiliki nilai $\mathrm{r}$ hitung lebih kecil dari nilai $r$ table. Oleh karena itu butir pertanyaan 1, 2, 3, 4 dan 6 harus dibuang dan dilakukan uji validitias ulang dengan hanya 2 pertanyaan.

\section{Tabel 5 \\ Hasil Uji Validitas (Ulang) Variabel X}

\begin{tabular}{||r|r|r|r|r|}
\hline \multicolumn{5}{|c|}{ Item-Total Statistics } \\
\hline & $\begin{array}{c}\text { Scale Mean if } \\
\text { Item Deleted }\end{array}$ & $\begin{array}{c}\text { Scale } \\
\text { Variance if } \\
\text { Item Deleted }\end{array}$ & $\begin{array}{c}\text { Corrected } \\
\text { Item-Total } \\
\text { Correlation }\end{array}$ & $\begin{array}{c}\text { Cronbach's } \\
\text { Alpha if Item } \\
\text { Deleted }\end{array}$ \\
\hline PX.5 & 4.65 & .315 & .612 & \\
PX.7 & 4.38 & .566 & .612 & \\
\hline
\end{tabular}

Sumber : diolah penulis

Berdasarkan hasil perhitungan ini, dapat disimpulkan dua indikator pertanyaan variabel $\mathrm{X}$ memiliki $\mathrm{r}$ hitung yang lebih besar dari nilai $r$ tabel telah valid.

\section{Uji Reliabilitas}

Uji Reabilitas Variabel Y1:

Reabilitas suatu konstruk variabel dikatakan baik jika memiliki nilai Cronbach's Alpha> dari 0,60. Maka berdasarkan hasil ini dapat dilihat bahwa Cronbach's Alpha $0.830>$ dari 0,60. Hal ini berarti jawaban responden untuk variabel Y1 sudah reliabel.

Tabel 6.

Hasil Uji Reabilitas Variabel Y1

Reliability Statistics

\begin{tabular}{|c|r|}
\hline $\begin{array}{c}\text { Cronbach's } \\
\text { Alpha }\end{array}$ & N of ltems \\
\hline .877 & 5 \\
\hline
\end{tabular}

Sumber : diolah penulis 
Uji Reabilitas Variabel Y2:

Reabilitas suatu konstruk variabel dikatakan baik jika memiliki nilai Cronbach's Alpha> dari 0,60. Maka berdasarkan hasil ini dapat dilihat bahwa Cronbach's Alpha 0.830 > dari 0,60. Hal ini berarti jawaban responden untuk variabel Y2 sudah reliabel.

Tabel 7 Hasil Uji Reabilitas Variabel Y2

Reliability Statistics

\begin{tabular}{|r|r|}
\hline $\begin{array}{c}\text { Cronbach's } \\
\text { Alpha }\end{array}$ & N of Items \\
\hline .949 & 5 \\
\hline
\end{tabular}

Sumber : diolah penulis

Uji Reabilitas Variabel X:

Reabilitas suatu konstruk variabel dikatakan baik jika memiliki nilai Cronbach's Alpha> dari 0,60. Maka berdasarkan hasil ini dapat dilihat bahwa Cronbach's Alpha $0.830>$ dari 0,60. Hal ini berarti jawaban responden untuk variabel X sudah reliabel.
Tabel 8

Hasil Uji Reabilitas Variabel $\mathbf{X}$

Reliability Statistics

\begin{tabular}{|c|r|}
\hline $\begin{array}{c}\text { Cronbach's } \\
\text { Alpha }\end{array}$ & N of Items \\
\hline .739 & 2 \\
\hline
\end{tabular}

Sumber : diolah penulis

Setelah memastikan seluruh data telah valid, sudah reliabel dan nilai interval sudah dijumlahkan. Dari seluruh Pertanyaan pada setiap variabel ( $\mathrm{Y} 1, \mathrm{Y} 2$, dan $\mathrm{X}$ ) masing masing dijumlah untuk setiap variabel. Jika total nilai interval telah ditotalkan, maka data tersebut siap dikorelasi dan diregresi seperti cara yang umum.

\section{Analisis Regresi}

Adapun variabel dalam penelitian ini adalah sebagai berikut,

1. Variabel bebas atau independen (X) yaitu prinsip mengenal nasabah (KYC)

2. Variabel terikat atau dependen (Y) yang meliputi :

a. Money Laundering

b. Kinerja Keuangan

Dengan menggunakan variabel-variabel di atas, 
penulis membentuk dua buah persamaan, yaitu persamaan pertama :

$$
\gamma_{1}=\alpha+\beta \chi_{1}
$$

untuk melihat apakah ada pengaruh dari faktor $\mathrm{X}_{1}$ yaitu (KYC) terhadap $\mathrm{Y}_{1}$ (Money Laudering) dalam perusahaan perbankan.

Dan persamaan kedua yaitu :

$$
\gamma_{2}=\alpha+\beta \chi_{1}
$$

untuk melihat apakah ada pengaruh dari faktor $\mathrm{X}_{1}$ yaitu (KYC) terhadap $\mathrm{Y}_{2}$ (Kinerja Keuangan) dalam perusahaan perbankan.

\section{Tabel 9}

\section{Hasil Uji Korelasi Variabel X dan Y1}

\begin{tabular}{|c|c|c|c|c|}
\hline \multicolumn{5}{|c|}{ Correlations } \\
\hline & & & $J \mathrm{Jmlh} . \mathrm{X}$ & Jmlh.Y1 \\
\hline \multirow[t]{6}{*}{ Spearman's rho } & $J \operatorname{Jmlh} . X$ & Correlation Coefficient & 1.000 & .074 \\
\hline & & Sig. (2-tailed) & . & .719 \\
\hline & & $N$ & 26 & 26 \\
\hline & Jmlh.Y1 & Correlation Coefficient & .074 & 1.000 \\
\hline & & Sig. (2-tailed) & .719 & . \\
\hline & & $N$ & 26 & 26 \\
\hline
\end{tabular}

\section{$\rightarrow$ Nonparametric Correlations}

Sumber : diolah penulis

Berdasarkan hasil running data melalui SPSS dapat dilihat bahwa tingkat hubungan antara variabel $\mathrm{X}$ (implementasi KYC) dan Y1 (terdeteksinya money laundering) positif lemah dengan nilai korelasi 0,074 .

Tabel 10

Hasil Uji Korelasi Variabel X dan Y2

\begin{tabular}{|c|c|c|c|c|}
\hline \multicolumn{5}{|c|}{ Correlations } \\
\hline & & & Jmlh.X & Jmlh.Y2 \\
\hline \multirow[t]{6}{*}{ Spearman's rho } & Jmlh.X & Correlation Coefficient & 1.000 & .096 \\
\hline & & Sig. (2-tailed) & & .640 \\
\hline & & N & 26 & 26 \\
\hline & Jmlh.Y2 & Correlation Coefficient & .096 & 1.000 \\
\hline & & Sig. (2-tailed) & .640 & \\
\hline & & $\mathrm{N}$ & 26 & 26 \\
\hline
\end{tabular}

\section{$\Rightarrow$ Nonparametric Correlations}

Sumber : diolah penulis

Berdasarkan hasil running data melalui SPSS dapat dilihat bahwa tingkat hubungan antara variabel X (implementasi KYC) dan Y2 (tingkat kinerja keuangan perbankan) negatif lemah dengan nilai korelasi -0,096. 
Tabel 11

Hasil Uji Regresi Variabel X

dan Y1

Model Summary

\begin{tabular}{|l|c|r|r|r|}
\hline Model & $R$ & $R$ Square & $\begin{array}{c}\text { Adjusted } R \\
\text { Square }\end{array}$ & $\begin{array}{l}\text { Std. Error of } \\
\text { the Estimate }\end{array}$ \\
\hline 1 & $.135^{\text {a }}$ & .018 & .023 & 4.97236 \\
\hline
\end{tabular}

a. Predictors: (Constant), Jmlh.X

ANOVA ${ }^{\mathrm{a}}$

\begin{tabular}{|c|c|c|c|c|c|c|}
\hline Mode & & $\begin{array}{l}\text { Sum of } \\
\text { Squares }\end{array}$ & df & Mean Square & $F$ & Sig. \\
\hline \multirow[t]{3}{*}{1} & Regression & 10.962 & 1 & 10.962 & \multirow[t]{3}{*}{.443} & \multirow[t]{3}{*}{$.512^{b}$} \\
\hline & Residual & 593.384 & 24 & \multirow[t]{2}{*}{24.724} & & \\
\hline & Total & 604.346 & 25 & & & \\
\hline
\end{tabular}

a. Dependent Variable: Jmlh.Y1

b. Predictors: (Constant), Jmlh.X

Coefficients $^{\mathrm{a}}$

\begin{tabular}{|c|c|c|c|c|c|c|}
\hline \multirow[b]{2}{*}{ Model } & & \multicolumn{2}{|c|}{ Unstandardized Coefficients } & \multirow{2}{*}{$\begin{array}{c}\text { Standardized } \\
\text { Coefficients } \\
\text { Beta }\end{array}$} & \multirow[b]{2}{*}{$t$} & \multirow[b]{2}{*}{ Sig. } \\
\hline & & $B$ & Std. Error & & & \\
\hline 1 & (Constant) & 11.362 & 7.663 & & 1.483 & .151 \\
\hline & Jmlh.X & .560 & .841 & .135 & .666 & .512 \\
\hline
\end{tabular}

a. Dependent Variable: Imlh.Y1

Sumber : diolah penulis

Berdasarkan hasil running data melalui SPSS dapat dilihat bahwa tidak ada pengaruh antara variabel $\mathrm{X}$ (implementasi KYC) dan Y1 (terdeteksinya money laundering).

\section{Hasil Wawancara}

a. Bank Swasta

Implementasi KYC sudah diterapkan dengan baik dan hal ini tidak terlalu berpengaruh pada tingkat kinerja keuangan perbankan, khususnya DPK, dikarenakan nasabah mayoritas pada bank swasta merupakan nasabah transaksional. Dimana artinya nasabah memang membutuhkan bank tersebut untuk kegiatan transaksinya sehari-hari, dan nasabah memang merupakan nasabah yang memiliki loyalitas tinggi terhadap bank swasta tersebut.

b. Bank BUMN

Penerapan KYC sangat berpengaruh pada tingkat kinerja keuangan perbankan, khususnya DPK dikarenakan mayoritas nasabah adalah pegawai negeri dan BUMN. Sehingga saat ini para nasabah tersebut merasa enggan untuk menyimpan dananya di bank dan lebih memiih untuk menyimpan dana dalam alat investasi lainnya. Hal ini dikarenakan mereka merasa risih dengan 
adanya pengawasan yang lebih ketat terhadap rekening dan kegiatan transaksi mereka.

Tabel 12

Hasil Uji Regresi Variabel X dan Y2

Model Summary
\begin{tabular}{|l|c|r|r|r|}
\hline Model & \multicolumn{1}{|c|}{$R$} & R Square & $\begin{array}{l}\text { Adjusted R } \\
\text { Square }\end{array}$ & $\begin{array}{l}\text { Std. Error of } \\
\text { the Estimate }\end{array}$ \\
\hline 1 & $.169^{\mathrm{d}}$ & .028 & -012 & 5.95682 \\
\hline
\end{tabular}

a. Predictors: (Constant), Jmlh.X

\begin{tabular}{|c|c|c|c|c|c|c|}
\hline \multicolumn{7}{|c|}{ ANOVA ${ }^{a}$} \\
\hline \multicolumn{2}{|c|}{ Model } & $\begin{array}{l}\text { Sum of } \\
\text { Squares }\end{array}$ & df & Mean Square & $F$ & Sig. \\
\hline \multirow[t]{3}{*}{1} & Regression & 24.892 & 1 & 24.892 & .701 & $.411^{b}$ \\
\hline & Residual & 851.608 & 24 & 35.484 & & \\
\hline & Total & 876.500 & 25 & & & \\
\hline
\end{tabular}

a. Dependent Variable: Jmlh. Y2

b. Predictors: (Constant), Jmlh.X

Coefficients $^{\mathrm{a}}$

\begin{tabular}{|c|c|c|c|c|c|c|}
\hline \multirow[b]{2}{*}{ Model } & & \multicolumn{2}{|c|}{ Unstandardized Coefficients } & \multirow{2}{*}{$\begin{array}{c}\begin{array}{c}\text { Standardized } \\
\text { Coefficients }\end{array} \\
\text { Beta }\end{array}$} & \multirow[b]{2}{*}{$t$} & \multirow[b]{2}{*}{ Sig. } \\
\hline & & $B$ & Std. Error & & & \\
\hline \multirow[t]{2}{*}{1} & (Constant) & 26.127 & 9.180 & & 2.846 & .009 \\
\hline & $\operatorname{Jmlh} . X$ & .844 & 1.007 & .169 & .838 & .411 \\
\hline
\end{tabular}

a. Dependent Variable: Jmlh. Y2

\section{Sumber : diolah penulis}

Berdasarkan hasil running data melalui SPSS dapat dilihat bahwa tidak ada pengaruh antara variabel $\mathrm{X}$ (implementasi KYC) dan Y2 (tingkat kinerja keuangan perbankan).

\section{PENUTUP}

Dilihat dari hasil statistik deskriptif sekitar $60 \%$ sd. $70 \%$ koresponden yang menyatakan ada pengaruh dari implementasi KYC terhadap terindikasinya money laundering dan kinerja keuangan (DPK) perbankan. Akan tetapi melalui hasil uji statistik diketahui bahwa tidak ada pengaruh yang signifikan baik dari implementasi KYC terhadap Money Laundering maupun dari implementasi KYC terhadap kinerja keuangan (DPK) perbankan.

Hal ini didukung oleh hasil wawancara, dimana bank swasta menyatakan tidak terlalu terpengaruh akan implementasi KYC ini, dikarenakan nasabah yang ada memang karena nasabah transaksional, berbeda dengan bank BUMN yang mayoritas menyatakan bahwa sangat terpengaruh karena nasabah yang ada merupakan nasabah dari PNS dan karyawa BUMN. Dikarenakan jumlah responden ada 26 bank dan mayoritas adalah bank swasta, sehingga hasil penelitian ini lebih 
condong kepada hasil yang tidak berpengaruh signifikan.

Penelitian ini dapat dikembangkan lagi menjadi beberapa penelitian yang mungkin dapat dibedakan menjadi penelitian untuk bank BUMN dan bank swasta untuk lebih jauh melihat tingkat perbedaannya. Penelitian ini juga dapat dikembangkan untuk melihat seberapa jauh terpengaruhnya kinerja keuangan (DPK) perbankan secara kuantitatif.

\section{DAFTAR PUSTAKA}

Basuki, Sulistyo. 2010. Metode Penelitian. Jakarta: Penaku

Darwin, P. 2012. Money Laundering: Cara Memahami Dengan Tepat dan Benar Soal Pencucian Uang. Sidoarjo: Sinar Ilmu.

Hansen, Louis Simon. 2012. Prinsip Mengenal Nasabah (KYC) Sebagai Upay Pencegahan dan Pemberantasan Praktek Pencucian Uang Melalui Transfer Dana. Tesis Fakultas Hukum Program Pascasarjana Universitas Indonesia.

Hasan, Iqbal. 2006. Analisis Data Penelitian dengan Statistik. Jakarta: Bumi Aksara

Idroes, F. \& Sugiarto. 2006. Manajemen Resiko Perbankan:Dalam Konteks Kesepakatan Basel dan Peraturan Bank Indonesia. Jakarta: Graha Ilmu.

Jogiyanto HM. 2013. Pedoman Survei Kuesioner. BPFE-Yogyakarta Anggota IKAPI.

Kumar,Vandana Ajay. 2012. Money Laundering: Concept, Significance and its Impact. European Journal of Business and Management. ISSN 2221905 (Paper) ISSN 2222-2839 (Online). Vol 4. No.2, hal 113-120. McLaughlin, Josetta S., dan Deborah Pavelka. 2013. The Use Of Customer DueDiligenceTo Combat Money Laundering. Accountancy Business and the Public Interest 2013, hal 57-83.

Metekohy, Elisabeth Y., dan Ida Nurhayati. 2012. Efektifitas Prinsip Mengenal Nasabah (KYC) Pada Bank Sebagai Salah Satu Upaya Mencegah 
Tindak Pidana Pencucian Uang. Jurnal Ekonomi dan Bisnis (Politeknik Negeri Jakarta). Vol. 11 No.1 Juni 2012: 23-26.

Nasution, Edi. 2011. Memahami Praktik Pencucian Uang Hasil Kejahatan. Dokumen KPK.

Peraturan Bank Indonesia No. 11/28/PBI/2009 - Penerapan Program Anti Pencucian Uangdan Pencegahan Pendanaan Terorisme Bagi Bank Umum

Peraturan Bank Indonesia No. 12/20/PBI/2010 - Penerapan Program Anti Pencucian Uang (APU) dan Pencegahan Pendanaan Terorisme (PPT) bagi Bank Perkreditan Rakyat dan Bank Pembiayaan Rakyat Syariah

Prochnow, Herbert V. 2012. Bank Liquidity and the New Doctrine of Anticipated Income. The Journal of the American Finance Association Volume 4 Issue \$ Pages 298-314 December 1949.

Reuter, Peter dan E.M. Truman. 2004.The International Economy, Chasing DirtyMoney:The Fight Against Money Laundering. Institute for InternationalEconomics.

Sudjana. (2001). Metoda Statistika. Bandung: Tarsito.

Surat Edaran Bank Indonesia No.11/31/DPNP - Pedoman Standar Penerapan Program Anti Pencucian Uang dan Pencegahan Pendanaan Terorisme bagi Bank Umum

Surat Edaran Bank Indonesia No.13/14/DKBU/2011 Tanggal 12 Mei 2011 Tentang Penerapan Program Antipencucian Uang Dan Pencegahan Pendanaan Terorisme Bagi Bank Perkreditan Rakyat Dan Bank Pembiayaan Rakyat Syariah

Surat Edaran No. 6/37/DPNP tanggal 10 September 2004 perihal Penilaian danPengenaan Sanksi atas Penerapan Prinsip Mengenal Nasabah (KYC) dan Kewajiban Lain Terkait dengan Undang-Undang tentang Tindak Pidana Pencucian Uang dan lampiran

Undang-Undang Republik Indonesia No.8 tahun 2010 tentang Pencegahan DanPemberantasan Tindak Pidana Pencucian Uang 
Undang-Undang Republik Indonesia No.15 tahun 2003 tentang Penetapan Peraturan Pemerintah Pengganti Undang-Undang No. 1 tahun 2002 tentang Pemberantasan Tindak Pidana Terorisme menjadi UndangUndang 


\section{Lampiran \\ Ringkasan Penelitian Terdahulu}

\begin{tabular}{|c|c|c|c|}
\hline No. & Nama, Judul & Masalah & Hasil \\
\hline 1. & $\begin{array}{l}\text { Josetta S. McLaughlindan } \\
\text { Deborah Pavelka, "The } \\
\text { Use of Customer Due } \\
\text { Diligence to Combat } \\
\text { Money Laundering" } \\
\text { (2013) }\end{array}$ & $\begin{array}{l}\text { Peranan Customer Due } \\
\text { Diligencer } \quad \text { (CDD) } \\
\text { berdasarkan Know Your } \\
\text { Customer (KYC) dalam } \\
\text { memerangi pencucian } \\
\text { uang di area perbankan. }\end{array}$ & $\begin{array}{l}\text { Merupakan hal yang pentingdalam } \\
\text { menerapkan CDD berdasarkan } \\
\text { prinsip KYC, selain itu penggunaan } \\
\text { prinsip KYC di identifikasi sebagai } \\
\text { komponen terpenting untuk AML } \\
\text { (Anti Money Laundering) }\end{array}$ \\
\hline 2 & $\begin{array}{l}\text { Vandana } \\
\text { "Money }\end{array}$ & $\begin{array}{ll}\text { Bagaimana } & \text { konsep, } \\
\text { signifikansi dan dampak } \\
\text { dari pencucian uang. }\end{array}$ & $\begin{array}{l}\text { Bankir memainkan peran yang } \\
\text { paling menonjol ditambah dengan } \\
\text { pengembangan baru berteknologi } \\
\text { tinggi mempersulit untuk mendeteksi } \\
\text { pergerakan dana gelap. }\end{array}$ \\
\hline 3 & $\begin{array}{lrr}\text { Elisabeth } & \text { Y } & \text { Metekohy } \\
\text { dan Ida } & \text { Nurhayati, } \\
\text { "Efektivitas } & \text { Prinsip } \\
\text { Mengenal } & \text { Nasabah } \\
\text { (KYC) } & \text { Pada } & \text { Bank } \\
\text { Sebagai } & \text { Salah } & \text { Satu } \\
\text { Upaya } & \text { Mencegah } & \text { Tindak } \\
\text { Pidana } & \text { Pencucian } & \text { Uang" } \\
\text { (2012) } & & \end{array}$ & $\begin{array}{l}\text { Penerapan KYC harus } \\
\text { diambil baik oleh } \\
\text { pemerintah maupun } \\
\text { masyarakat,mengingat } \\
\text { dampaknya tidak hanya } \\
\text { terhadapindividu, } \\
\text { melainkan negara dan } \\
\text { masyarakatluas. }\end{array}$ & $\begin{array}{l}\text { Tahap placement/penempatan } \\
\text { denganmodus operandi pelaku dalam } \\
\text { menangani uangtunai (cash) adalah } \\
\text { sebagai berikut : } \\
\text { - Conservation of Cash } \\
\text { - Structuring Cash Deposit } \\
\text { - Smurfing } \\
\text { - International Smuggling of Cash }\end{array}$ \\
\hline 4 & 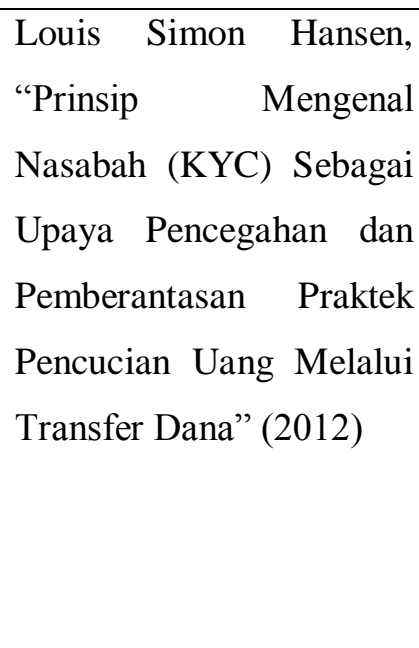 & $\begin{array}{lr}\text { Mencoba } & \text { meneliti } \\
\text { seberapa } & \text { penting } \\
\text { penerapan } & \text { Prinsip } \\
\text { Mengenal } & \text { Nasabah } \\
\text { (KYC) untuk mencegah } \\
\text { praktek tindak } & \text { pidana } \\
\text { pencucian uang. } & \end{array}$ & $\begin{array}{l}\text { Dalam Prinsip Mengenal Nasabah } \\
\text { (KYC) terkandung lima elemen } \\
\text { pokok, yaitu kebijakan dan prosedur } \\
\text { yang jelas tentang penerimaan } \\
\text { nasabah, CDD dan EDD, pengkinian } \\
\text { dan pemantauan berkelanjutan } \\
\text { terhadap rekening dan transaksi } \\
\text { nasabah, pelaporan transaksi } \\
\text { keuangan mencurigakan, dan } \\
\text { manajemen risiko. }\end{array}$ \\
\hline
\end{tabular}




\begin{tabular}{|c|c|c|c|c|}
\hline 5 & $\begin{array}{lr}\text { Edi } & \text { Nasution, } \\
\text { "Memahami } & \text { Praktik } \\
\text { Pencucian Uang Hasil } \\
\text { Kejahatan" (2011) }\end{array}$ & $\begin{array}{l}\text { Memaham } \\
\text { Pencucian } \\
\text { Kejahatan }\end{array}$ & $\begin{array}{rr} & \text { Praktik } \\
\text { Uang } & \text { Hasil }\end{array}$ & $\begin{array}{l}\text { Praktik pencucian masih } \\
\text { tetap berlangsung kalau masih saja } \\
\text { ada orang atau korporasi yang mau } \\
\text { terlibat dalam kegiatan kriminal } \\
\text { yang menghasilkan keuntungan } \\
\text { ilegal. Oleh karena itu, institusi } \\
\text { penegak hukum dan aparatnya harus } \\
\text { bertindak proaktif dan kalau perlu } \\
\text { berpikir, tetapi bukan bertindak, } \\
\text { seperti para pelaku pencucian uang. }\end{array}$ \\
\hline
\end{tabular}

